\title{
The Levers of Management Control System in Organizational Life Cycle
}

\section{Saarce Elsye Hatane, Lisa Gabrielle, and Sarah Febe Angelina}

Business Accounting Department, Petra Christian University, Surabaya, East Java, Indonesia

\section{Abstract}

This article discusses the application of management control system (MCS) in each stage of organizational life cycle (OLC). MCS is described using Simon's (1995) levers of control (belief, boundary, interactive, and diagnostic control system). This study explains OLC in four stages, namely, birth, growth, maturity, revival, and is measured using eight indicators (environment uncertainty; the influence of board, owners, and shareholders; decentralization of authority; strategic planning; diversification; marketing and distribution; innovation; managers' focus on decision-making). This study was conducted on 37 limited liability companies in Indonesia by distributing questionnaires in the form of Likert scales to managers. The data is processed using Compare Means

Corresponding Author: Saarce Elsye Hatane elsyehat@petra.ac.id

Received: 29 January 2019 Accepted: 27 February 2019 Published: 24 March 2019

Publishing services provided by Knowledge E

(c) Saarce Elsye Hatane et al. This article is distributed under the terms of the Commons Attribution License, which permits unrestricted use and redistribution provided that the original author and source are credited.

Selection and Peer-review under the responsibility of the $3 \mathrm{rd}$ ICEEBA Conference Committee. One-way ANOVA. The results indicate that belief, boundary, and interactive, diagnostic control system are used to a greater extent in revival stage. This article provides information for managers about type of controls that are often used in each of the OLC stage, thus managers are able to decide the right MCS in managing the strategy for the company.

Keywords: organizational life cycle, management control system, levers of control

\section{Introduction}

Dynamic organizational characteristics have been modeled in various stages of the life cycle. Previous research has found that various organizational characteristics, such as size, age, and strategy, often follow certain patterns, making it possible to group organizations into various stages of the life cycle [1]. The stages in organizational life cycle (OLC) reflect the level of organizational development, where each stage reflects integral complementarity. This can be seen from the simultaneous development of various contingent variables that are used as a measurement tool for each stage in OLC [2, 3]. Dynamic configuration form by grouping organizations into various stages of development, based on four contingent variables (organizational situation, strategy, structure and decisionmaking style) [2]. These are the OLC stages, consisting of birth, growth, maturity and revival. Birth itself is the earliest stage in the OLC and the period where a company is 
starting its business to become an entity that can survive in the market. The second stage is growth, the period that occurs when a company has established a unique competency and enjoys success over the initial product or market. Maturity occurs when a company is more mature, from a stable level of sales to a bureaucratic organizational structure. And finally, revival, market and product diversification and expansion usually occur at this stage.

On the other hand, the organization is a group of people who work together to achieve the common goal. Managers have to make sure that their subordinate behavior is beneficial or has an impact on the organization in order to achieve the goals [1]. Managers monitor the process using Management Control Systems (MCS) as tools. Most of the literature discusses MCS by focusing more on examining the presence, character and or importance of controls, but lacking focus on examining the way in which control is used [4] and its impact on the organization's financial performance. Strategies emerge through experiments that are influenced by MCS [5]. Based on that perspective, MCS is important to be applied in organizations because MCS can influence the development of strategies. Many previous studies have recommended studying all components of MCS as an inseparable package $[4,6]$. However, many studies only focus on some MCS components, or on certain MCS measurements. This is because of the fact that the data needed to study a fully complete MCS can be very wide. Therefore, MCS becomes difficult to analyze. The implication is that this limitation has the potential to produce diverse and possibly contradictory research results [7].

There have been many previous studies that measured MCS using a lever of controls initiated by Simons in 1995 [3, 4, 8-11]. The four levers of control are belief, boundary, diagnostic and interactive. Most studies of management control systems have focused on interactive and diagnostic control systems [4, 8-11]. Compared to the other two, interactive and diagnostic control pay attention more in the relevance of the way where control is applied [8]. In previous studies suggest that interactive control and diagnostic control allow different comparisons of control in the way they are used [3,12-14]. Learning from the limitations of the results of previous studies that focused more on interactive and diagnostic control, this study measures MCS by using all four levers of control.

The aims of this research is to contribute to the existing literature by examining the relationship between the four stages of organizational life cycle from the Miller and Friesen model in 1984 [2] (birth, growth, maturity and revival) to the levers of control of the Simons in 1995 [15] (belief, boundary, diagnostic control and interactive control). From the background above, this research has the following problem formulation: Are there differences in the application of levers of control in each stage of the organizational 
life cycle? This research is useful for management to increase the company's awareness of the importance of levers of control at every stage of OLC. This knowledge can provide insight for management to be able to use the appropriate levers of control for each stage of the company's organizational life cycle.

\section{Literature Review and Hypothesis}

\subsection{Organizational life cycle}

The concept of the organizational life cycle model was introduced by [16] which explained that changes in the organization follow a pattern that is consistent and predictable, and characterized by different stages of development. When companies change over one to another stages, they will experience different structural configurations, problems, organizational characteristics, and strategic or management priorities [17-19]. The OLC theory states that organizational characteristics such as structure, strategy, leadership style, critical development areas and the company's environmental conditions vary at each stage in the organization's life cycle [20-24].

From research conducted by [2], introducing a model for the life cycle of an organization or company, which can be classified into five stages, namely birth, growth, maturity, revival and decline. The model was chosen because it covers all organizational life from birth to death and has been empirically tested and supported in the organizational life cycle literature [2, 25-28]. In addition, the Miller and Friesen OLC models provide quantitative measurements at the stage of the organizational life cycle. In the first four stages, the size and age of the organization, as well as its environmental competitiveness, increase. Whereas in the last stage, there is a decline in profitability and the company, and the market also decrease. Stage decline is not used in research because at this stage, organizations are difficult to identify through survey instruments because change occurs metamorphically and cannot be predicted $[23,29,30]$. Therefore, in this study four initial stages of the organizational life cycle are used.

\subsection{Levers of control (Management control system)}

Management control system is explained as formal systems and procedures that use information to maintain or change patterns of activity within the organization [31]. The management control system represents the organization's desire to achieve its goals by providing information that is useful in decision-making, planning and performance 
evaluation [32-34]. There are four types of management control systems that work together as levers of control (LOC), namely belief, boundary, interactive and diagnostic control systems. This LOC must be used equally to execute the effective strategy [ 15 , $35,36]$.

The relationship between the use of control systems throughout the organizational life cycle is based on upper echelon theory which shows that management acts based on their personal interpretation of the strategic situation they face [37]. This research applies the stage of organizational life cycle as a proxy of 'strategic situation' and examines how organizational situations, strategies, structures and decision-making styles influence the selection of management approaches to use controls [28].

\subsubsection{Boundary control in organizational life cycle}

When organizations are in the life cycle of birth, organizations will focus on developing and innovating product lines. Organizations tend to be more proactive toward competitors by creating new products and practices to defeat competitors, thus encouraging organizations to take big risks. On the other hand, if the company uses boundary control, it will create a system of policy boundaries and guidelines to limit the search for opportunities. Boundary control systems is used to avoid risk by setting limits and enforcing rules such as, codes of conduct, strategic planning systems, operating directions [38]. At the growth stage, the structure gets more complex and less centralized. Hence, the organizations need managers' analytical skill to make decisions since there are more factors to be considered [28]. This situation brings about risks for organization, such as subordinates behave for their own interests. Subordinates will have increasing freedom since decision-making is delegated to them [36]. At the growth phase, boundary system is used to prohibit managers from some activities [1]. Even though, organization needs to empower their employees in growth stage, that doesn't mean the organization can do anything they like. There must be guidelines that clearly state the type of behavior that is prohibited, and these must come from senior managers, who responsible to determine the type of dysfunctional behavior that has the potential to damage the organization.

In the maturity stage, the organization does not pursue diversification and innovation, but emphasizes improvements in productivity and efficiency. This makes the product scope narrower than in the growth stage [39]. Emphasis on productivity and efficiency goes hand in hand with decision-making styles that are less innovative, less proactive and more risk averse [28, 39, 40]. Reference [36] argues that the diagnostic control system approach has an important role in achieving organizational efficiency and goals. This 
indicates that the diagnostic control system is more suitable for use than the boundary control system. Thus, the use of the boundary control system is expected to be used at a lower level in the maturity stage than the growth stage.

At the revival stage, organizations have the greatest size, environmental change and higher competitive levels, as well as the most dispersed ownership among all stages of the organizational life cycle. Organizations generally focus on significant diversification and innovation in products and markets, as well as expanding the market for their products to achieve new turnover and growth among highly competitive markets [39]. Organizations tend to implement a differentiated strategy that requires more creativity in competing. This is in accordance with the use of the boundary approach, because the purpose of the boundary system is to enable employees to have freedom to innovate, explore, create and achieve certain standards [36]. It is also supported by [41], although the boundary system explains business guidelines, it can be used in conjunction with the boundary control system to enhance creativity.

Organizations at the revival stage have performed more formal analysis in decisionmaking. This decision-making style tends to be more flexible and analytical so that it can mitigate high-level risks, such as increasing market heterogeneity. Organization overcomes that risk using the authority over operating decisions that are delegated to each section of the organization structure. Also, the performance of each division is a responsibility of the division manager [39]. For this reason, boundary control is used at this stage to empower employees to use their own judgment and wisdom to make decisions and innovate new ideas. Even though the limitations are stated in the work, this limitation can help achieve flexibility and creativity. Since the subordinates comply with the boundaries, the manager can allow subordinates to make their own decisions without managers role [1]. In this condition, boundary control can involve both in operational effectiveness and employee creativity which is increasing the company's competitiveness. Thus, the use of boundary control is used at a greater level in the revival stage than the maturity stage. Therefore, this study argues that the boundary control system approach will be used at a greater level in the growth stage and revival rather than birth and maturity in the organizational life cycle stage.

$\mathrm{H} 1$ : Boundary control system is expected to be applied in the greater extent at growth and revival stages than at birth and maturity stages in the organizational life cycle. 


\subsubsection{Belief control in organizational life cycle}

Creativity arises when management is encouraged to be more maximal, and when the task is not coordinated in a systematic way but 'frantic'. In the birth period, the company is structurally and financially unstable, and the decision-making process is simple and fast, the leader or the owner is responsible for everything [42]. This indicates that in the birth stage there is still no formal system used by managers to define, communicate the company's core values to give inspiration and motivation for employees to take appropriate actions. In addition, decision-making is still centralized. Thus, the belief control system is still less used when at the birth stage. Reference [15] notes that belief control systems, such as formal values, usually appear in the growth stage after the introduction of the boundary system. As long as the organization is at the growth stage, the focus of the organization is to pursue rapid sales growth [2]. In [43], said that the vision of the founder of the company can help attain growth quickly. The company is growing fast either by acquiring new units through acquisitions or by building new units [1]. In addition, organizations that are at the growth stage will continue to strive to dominate the market. The organization will use analysis and strategies to continue to achieve certain growth targets [2]. This, of course, requires a belief control system to continue to motivate employees to achieve these growth targets. According to [15], belief control system, through its mission and vision, can be used to establish a guideline in work targets, as well as regulate the behavior of employees who are in pursuit of these targets. Thus, the use of the belief control system is more applicable to a higher life cycle than birth.

Organizations in the maturity stage are conservative. They don't do many big innovations. Therefore, the maturity stage shows that decision-making styles are less innovative, less proactive, and more risk averse than in other phases. Organizations focus more on solving problems immediately and give less emphasis to formulating strategies explicitly [2]. According to [15], the use of belief systems when organizations seek opportunities and plan strategies. Therefore, the use of belief system is used at a lower level in the maturity stage than the growth stage. The decision-making style at the revival stage is an innovative, proactive, and risk-taking style. The company pursues rapid growth through innovation, acquisition, and diversification and this involves a lot of risk taking. It also encourages leaders to be more innovative than imitating competitor strategies [15]. This creates a lot of strategic changes, so the belief system is needed. Reference [35] claims that for organizations facing strategic change, belief systems are important for communicating core visions and values. This is in accordance with [1] which states that 
formal belief systems such as official missions and vision statements are implemented when organizations are increasingly mature. For this reason, the use of belief systems is used at a higher level of life cycle, which are at the stage of maturity and revival.

\section{$\mathrm{H}$ 2: Belief control system is expected to be applied in the greater extent at growth and revival stages than at birth and maturity stages in the organizational life cycle.}

\subsubsection{Diagnostic control in organizational life cycle}

Reference $[15,36]$ suggested that to confirm the effective diagnostic control system approach, organizational goals, and strategies, the keys of success must be explicit enough to set the correct outcome measurement. The organizations in birth stage go through an uncertain environment as they try to create produce in new markets [2]. This makes it difficult for organizations to set clear goals, strategies and success key. Therefore, a diagnostic approach is not expected to be used more frequently at the birth stage [28].

When organizations shift to the growth stage, there is a risk that employees act in their own importance since they have rights to make decision. The diagnostic approach is used to follow the progress of achieving goals and monitor results. Therefore, a diagnostic approach can be used to restrict undesirable manner to a certain level, in order to achieve organizational goals. Moreover, the diagnostic approach does not require as much as management attention compared to interactive approaches. Hence, managers can focus on more important decision-making activities, like organizational long-term planning. However, the growth stage tends to be more competitive and uncertain environment. It results difficulty to define the expected output accurately, which interfere the use of a diagnostic approach [36]. Therefore, similar to the birth stage, the diagnostic approach is not expected to be used in the growth stage.

When organizations are in the maturity stage, they have slower growth compared to growth stage. In maturity stage, organizations emphasize on production efficiency, since the environment is relatively stable. [44] argue diagnostic approaches are more effective in situations where the environment is stable, whereas [36] argues that the diagnostic control system approach is an important role in achieving organizational efficiency and goals. As mentioned that organizations in maturity stage have relatively stable environment (Miller and Friesen, 1984. Organizations can easily establish goals and desired outcomes, in order to ensure effective use of diagnostic approaches. [15, 36]. Furthermore, the maturity stage company has a highly structured communication 
channel, hence the use of a diagnostic approach is more appropriate [11]. Therefore, the diagnostic approach is expected to be used more frequently in the maturity stage than at the stage of birth and growth.

In the maturity stage, organizations focus on big innovation and large diversification than the maturity stage. Top management tends to focus more on strategic issues, in order to overcome heterogeneous, competitive and dynamic environments. The diagnostic control system approach helps management attention by relying on exception reporting to monitor results and review critical performance variables [36]. However, [45] argues that the diagnostic approach prevents employees to be creative, even though organizations need some innovation. This argument is supported by [15] who asserts that the diagnostic approach restricts the search for opportunities and innovation. Thus, the diagnostic approach is expected to be used for a lower level in the revival stage than in the maturity stage. Finally, this study argues that the diagnostic control system approach will be used more in the maturity and revival stages. Thus, the following hypothesis is developed:

\section{H3: Diagnostic control system is expected to be applied in the greater extent at maturity stage than at birth, growth and revival stages in the organizational life cycle}

\subsubsection{Interactive control in organizational life cycle}

Organizations in the birth stage have a centralized structure and top management makes all key decisions [2]. Therefore, organizations in the growth stage may requires fewer sharing information and interaction between employees. Moreover, top management in the growth stage is likely to focus on operational problems more than managerial problems. According to the concept of interactive control which requires face-to-face meetings at different hierarchical, interactive control approach is considered inappropriate for the birth stage [28].

Organizations in growth stage have a function-based structure. Hence, every department gets an important role in improving coordination and facilitating collaboration [2]. As a result, an interactive control approach that focuses on the interaction and ongoing exchange of information between different levels of management and in various functions [8,44], is highly important. According to the concept theory that growth stage is an innovative stage. Hence, the use of interactive approaches will assist organization to encourage the formation and collaboration of knowledge in the organization [11]. This is consistent with the arguments of [4] the use of interactive approaches can generate 
innovation, fresh ideas, and initiatives. Therefore, the interactive approach is expected to be used more frequently in the growth stage than in the birth stage.

When organizations are in maturity stage, there is an effort by top management to take over the decision-making that was previously delegated to subordinates when the organization is in the growth stage. This condition depicts that subordinates don't have much contribution in decision-making [2]. Align with interactive approach theory, decisions made by managers from various levels, is less used. Furthermore, when organization is in the maturity stage, it means they are in a relatively stable environment. Hence, managers in organizations have less frequency of debates and discussions about unstable environment. Therefore, the interactive approach is expected to be used at a lower maturity level than in the growth stage [28].

Organization must be able to overcome the slow growth and bad performance in revival stage. In order to achieve new turnaround and growth, organizational revival stages only focus on significant products, market diversification and innovation [2]. Reference [15] states that interactive approaches are very useful for organization in innovations, while [2] suggest that organizations must have ability to understand threats and opportunities in competitive and uncertain environment. In addition, [46] asserts that interactive approaches allow management at various levels to involve in frequent discussions and debates, thus helping companies to put themselves in unstable and uncertain environment Therefore, the interactive approach is expected to be used for levels that are more often in the revival stage than at the maturity stage. As stated in the following hypothesis, this study expects the interactive control system approach to be used more in the growth stage and revival than the stage of birth and maturity in organizational life cycle.

H4: Interactive control system is expected to be applied in the greater extent at growth and revival stages than at birth and maturity stages in the organizational life cycle.

\section{Methodology}

Figure 1 shows the analysis model in this study. It is used to analyze the application of management control system (MCS) in each stage of organizational life cycle (OLC). Data is collected by using questionnaire, and it is examined in the model by employing the independent sample $t$-test. The sampling technique is a non-profitability technique with the several criteria as follow: a). The company has a minimum life of 5 years. This criterion is intended to ensure that the company has been established for a long time 
so that it has information and systems that are in place. c). The number of employees at least 50 people. This criterion is to ensure the size of the company is feasible to have management organizational systems and information distribution. d). The minimum position of the respondent is in the level of supervisor or manager. This is to get valid and reliable information about the organization.

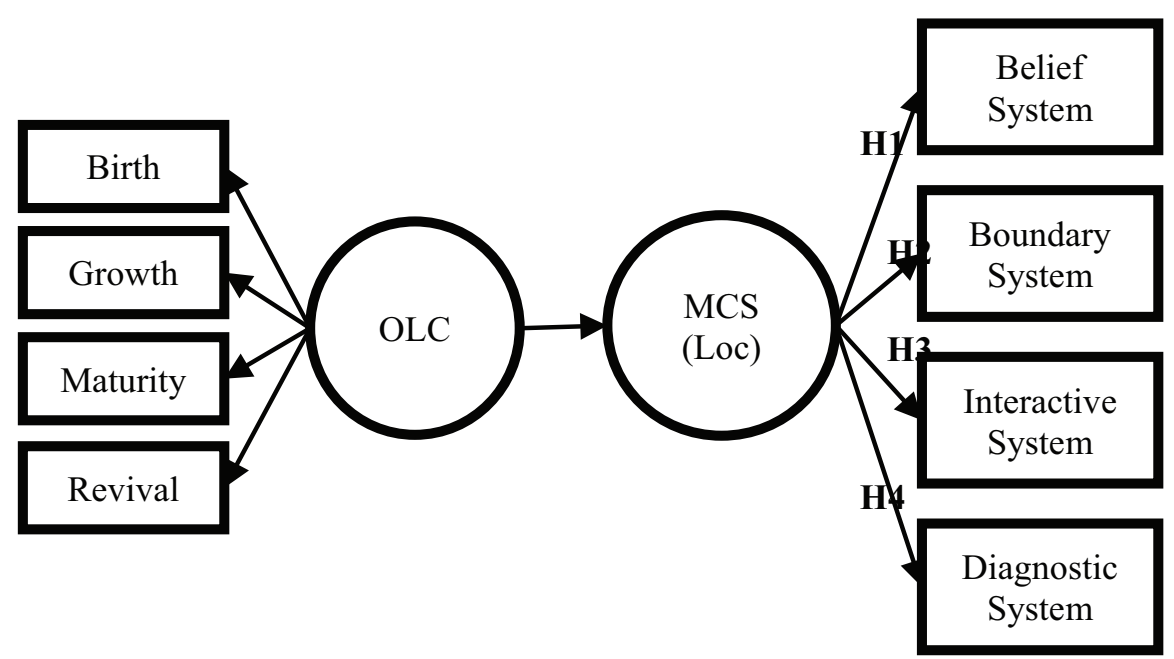

Figure 1: Research Model.

This study is conducted on 37 limited liability companies in Indonesia by distributing questionnaires in the form of five Likert scales to the managers. The questionnaires are adopted from previous researches by [3] for OLC and [47] for MCS. There are several steps to analyze data to avoid misinterpretation of data obtained. Data analysis techniques consist of validity test, reliability test and hypothesis test and the data are processed using Compare Means One-Way ANOVA.

\section{Findings}

The companies as the unit of analysis in this study are limited liabilities companies. The total sample of this study are 37 companies spread in East Java and Jakarta, 27\% in the form of listed companies, and the rest are non-listed companies. Most of the respondents come from the manufacturing industry by $37.8 \%$, followed by the trade industry by $21.6 \%$, and the rest came from other industries, such as service and construction industries. The respondents mostly occupy positions as managers, that is equal to $43.2 \%$, followed by supervisors at $29.7 \%$, and other positions such as directors. 


\begin{tabular}{|c|c|c|}
\hline $\begin{array}{l}\text { The Organizational Life Cycle } \\
\text { Indicators }\end{array}$ & $\begin{array}{c}\text { Mean } \\
\text { Total }\end{array}$ & $\begin{array}{c}\text { Corrected } \\
\text { Item-Total } \\
\text { Correlation } \\
\end{array}$ \\
\hline \multicolumn{3}{|l|}{ Environment uncertainty } \\
\hline $\begin{array}{l}\text { Dynamism (the unpredictability of } \\
\text { changes in customer tastes, production } \\
\text { technologies) }\end{array}$ & 3,92 & 0,643 \\
\hline $\begin{array}{l}\text { Hostility (the intensity of competition } \\
\text { and other external influences) }\end{array}$ & 4,05 & 0,7 \\
\hline $\begin{array}{l}\text { Heterogeneity (the differences in } \\
\text { competitive tactics, customer tastes, } \\
\text { product lines, channels of distribution) }\end{array}$ & 3,84 & 0,766 \\
\hline \multicolumn{3}{|c|}{ The influence of board, owners and shareholders } \\
\hline $\begin{array}{l}\text { The decisions and operations are } \\
\text { influenced by the boards of directors }\end{array}$ & 4,35 & 0,709 \\
\hline $\begin{array}{l}\text { The decisions and operations are } \\
\text { influenced by owners / shareholders }\end{array}$ & 4,08 & 0,778 \\
\hline \multicolumn{3}{|l|}{ Decentralisation of authority } \\
\hline Participative management & 3,95 & 0,695 \\
\hline $\begin{array}{l}\text { Effective internal communication } \\
\text { systems }\end{array}$ & 3,73 & 0,683 \\
\hline Delegation of decision-making & 3,78 & 0,728 \\
\hline Proactive decision-making & 3,7 & 0,675 \\
\hline \multicolumn{3}{|l|}{ Strategic planning } \\
\hline $\begin{array}{l}\text { Action planning (includes formal } \\
\text { strategic and project planning and review } \\
\text { procedures, the use of capital budgeting } \\
\text { techniques, and market forecasting) }\end{array}$ & 3,81 & 0,922 \\
\hline $\begin{array}{l}\text { Scanning (involves identification of } \\
\text { threats and opportunities in the external } \\
\text { environment of your business unit) }\end{array}$ & 3,65 & 0,926 \\
\hline \multicolumn{3}{|l|}{ Diversification } \\
\hline $\begin{array}{l}\text { Use acquisition to diversify into unrelated } \\
\text { lines }\end{array}$ & 3,38 & 0,857 \\
\hline Engages in vertical integration & 3,59 & 0,435 \\
\hline \multicolumn{3}{|l|}{ Marketing and distribution } \\
\hline Has major, frequent product innovations & 4,03 & 0,774 \\
\hline Dominates distribution channels & 3,7 & 0,643 \\
\hline $\begin{array}{l}\text { Extensive advertising and promotional } \\
\text { expenditure }\end{array}$ & 3,32 & 0,616 \\
\hline $\begin{array}{l}\text { Provides different product line for } \\
\text { different markets }\end{array}$ & 3,59 & 0,581 \\
\hline
\end{tabular}


TABLE 1: Respondents' Perception about OLC and Validity Items (Corrected Item-Total Correlation).

\begin{tabular}{|c|c|c|}
\hline \multicolumn{3}{|l|}{ Innovation } \\
\hline $\begin{array}{l}\text { Has small, incremental product } \\
\text { innovations }\end{array}$ & 3,38 & 0,755 \\
\hline $\begin{array}{l}\text { Selective in respect to the introduction } \\
\text { of new products }\end{array}$ & 3,81 & 0,737 \\
\hline \multicolumn{3}{|l|}{ Managers' focus on decision making } \\
\hline Centralisation of strategy formulation & 3,84 & 0,769 \\
\hline Extensive analysis of major decisions & 3,97 & 0,769 \\
\hline $\begin{array}{l}\text { Multiplexity of decisions (consideration } \\
\text { of a broad range of factors in making } \\
\text { strategic decisions) }\end{array}$ & 3,86 & 0,829 \\
\hline $\begin{array}{l}\text { Integration of decisions (Actions in one } \\
\text { area of the firm are complementary or } \\
\text { supportive of those in other areas (i.e., } \\
\text { divisions, functions) }\end{array}$ & 4 & 0,744 \\
\hline $\begin{array}{l}\text { Futurity of decisions (our business unit } \\
\text { incorporates a long-term planning } \\
\text { horizon relative to our industry) }\end{array}$ & 4,14 & 0,845 \\
\hline $\begin{array}{l}\text { Consciousness of strategies (concerns the } \\
\text { degree of your conscious commitment as } \\
\text { a business unit manager to an explicit } \\
\text { corporate strategy) }\end{array}$ & 3,95 & 0,859 \\
\hline $\begin{array}{l}\text { Adaptiveness of decisions (concerns the } \\
\text { responsiveness and appropriateness of } \\
\text { decisions to market requirements and } \\
\text { external environmental conditions) }\end{array}$ & 3,86 & 0,765 \\
\hline 3,83 & & \\
\hline
\end{tabular}

Table 1 shows that all the items in OLC measurement have higher correlated item values (higher than 0.3), which indicates that the items are valid. The respondent perceptions imply all observed companies are in the growth to revival stages in their organizational life cycle. Table 2 shows that all the items in MCS measurement have higher correlated item values (higher than 0.3), which indicates that the items are valid. The respondent perceptions imply all observed companies apply each of levers of control proportionally. As shown in Table 3, the Cronbach's Alpha values have met the standard, which is higher than 0.6. It indicates that all items are reliable. The Levene's numbers indicate that all indicators in MCS meet the homoscedasticity standard (the test $>0.05$ ), thus the ANOVA tests are all in the form of Bonferroni Test.

Based on the Table 4, the boundary control is used to a greater extent in revival stage for all organizational life cycle indicators. It reflects from the mean difference between 
TABLE 2: Respondents' Perception about MCS and Validity Items (Corrected Item-Total Correlation).

\begin{tabular}{|l|c|c|}
\hline $\begin{array}{l}\text { The Lever of Controls as } \\
\text { Manage ment Control System } \\
\text { Indicators }\end{array}$ & $\begin{array}{c}\text { Mean } \\
\text { Total }\end{array}$ & $\begin{array}{c}\text { Corrected } \\
\text { Item-Total } \\
\text { Correlation }\end{array}$ \\
\hline Belief System \\
\hline $\begin{array}{l}\text { Mission statement clearly communicates } \\
\text { the firm's core values to our workforce }\end{array}$ & 4,03 & 0,851 \\
\hline $\begin{array}{l}\text { Top managers communicate core values } \\
\text { to our workforce }\end{array}$ & 3,84 & 0,859 \\
\hline $\begin{array}{l}\text { Workforce is aware of the firm's core } \\
\text { values }\end{array}$ & 3,7 & 0,842 \\
\hline Mission statement inspires our workforce & 3,65 & 0,811 \\
\hline Boundary System & 3,89 & 0,87 \\
\hline $\begin{array}{l}\text { Firm relies on a code of business conduct } \\
\text { to defines appropriate behaviour for our } \\
\text { workforce }\end{array}$ & 3,89 & 0,837 \\
\hline $\begin{array}{l}\text { Firm has a system that communicates to } \\
\text { our workforce risks that should be } \\
\text { avoided }\end{array}$ & 3,78 & 0,915 \\
\hline $\begin{array}{l}\text { Workforce is aware of the firm's code of } \\
\text { business conduct }\end{array}$ & $\begin{array}{l}\text { Code of business conduct informs our } \\
\text { workforce about behaviours that are off- } \\
\text { limits }\end{array}$ & 3,78 \\
\hline
\end{tabular}

\begin{tabular}{|l|c|c|}
\hline \multicolumn{2}{|l|}{ The interactive use of control } & 0,748 \\
\hline $\begin{array}{l}\text { Controls are often used as a means of } \\
\text { developing ongoing action plans }\end{array}$ & 4,14 & 0,759 \\
\hline $\begin{array}{l}\text { Controls are used regularly in scheduled } \\
\text { face-to-face meetings between } \\
\text { operational and senior managers }\end{array}$ & 4,05 & 0,665 \\
\hline $\begin{array}{l}\text { There is a lot of on-going interaction } \\
\text { between operational management and } \\
\text { senior managers }\end{array}$ & 3,92 & 0,909 \\
\hline $\begin{array}{l}\text { Controls generate information that } \\
\text { forms an important and recurring agenda } \\
\text { in discussions between operational and } \\
\text { senior managers }\end{array}$ & 4,11 & 0,839 \\
\hline $\begin{array}{l}\text { Controls are used by operational and } \\
\text { senior managers to discuss changes that } \\
\text { are occurring within the business unit }\end{array}$ & 4,03 & 0,887 \\
\hline Diagnostic use of controls & 4,16 & 0,858 \\
\hline $\begin{array}{l}\text { Controls are used to track progress } \\
\text { towards goals and monitor results }\end{array}$ & 4,16 & 0,868 \\
\hline $\begin{array}{l}\text { Controls are used to plan how operations } \\
\text { are to be conducted in accordance with } \\
\text { the strategic plan }\end{array}$ & 4,19 & 0,889 \\
\hline $\begin{array}{l}\text { Controls are used to review performance } \\
\text { Controls are used to identify significant } \\
\text { exceptions from expectations and take } \\
\text { appropriate actions }\end{array}$ & 4,08 \\
\hline
\end{tabular}


TABLE 3: Reliability and Heteroscedasticity Result.

\begin{tabular}{|l|c|c|l|}
\hline & $\begin{array}{c}\text { Cronbach's } \\
\text { Alpha }\end{array}$ & Levine's Test & Test \\
\hline Belief & 0,836 & 0,127 & Bonferroni Test \\
\hline Boundary & 0,842 & 0,216 & Bonferroni Test \\
\hline Interactive Control & 0,812 & 0,632 & Bonferroni Test \\
\hline Diagnostic Control & 0,842 & 0,667 & Bonferroni Test \\
\hline
\end{tabular}

growth to maturity and growth to revival, which is growth to revival is bigger. Also, the use of boundary control has the biggest significance for environment uncertainty followed by strategic planning, innovation, and diversification. For market and distribution, boundary control is not significant in every stage, it means that boundary control is used equally in every stage. It reflects form the mean difference between every organizational stage which is not significantly different. The reason for boundary system is used to a greater extent for environment uncertainty because the boundary system overcomes heterogeneity, such as the differences in competitive tactics, customer tastes, product lines, and channels of distribution. In revival stage boundary system can be used to help employee innovating in the midst of business competition. While boundaries are in the work environment, those boundaries are able to achieve flexibility and creativity. As long as employees

follow the boundaries, they are allowed to make their own decisions without the role of managers. Boundary control contributes for operational effectiveness and employee creativity, moreover enhancing company competitiveness [1]. Regarding to the discussion, $\mathrm{H} 1$ is partially accepted.

TABLE 4: SPSS Test of Boundary Control System.

\begin{tabular}{|c|c|c|c|c|c|c|}
\hline \multicolumn{2}{|c|}{ Boundary Control } & \multirow[t]{2}{*}{ Env. Uncer } & \multirow{2}{*}{$\begin{array}{c}\text { Strat. Plan } \\
-1.1563\end{array}$} & \multirow{2}{*}{$\begin{array}{l}\text { Divers. } \\
-0.875\end{array}$} & \multirow{2}{*}{$\begin{array}{c}\text { Mark \& Dis } \\
-0.3333\end{array}$} & \multirow{2}{*}{$\begin{array}{l}\text { Innov. } \\
-1.0938\end{array}$} \\
\hline$B$ & G & & & & & \\
\hline & $M$ & & $-1.2917^{*}$ & -0.8465 & -0.65 & $-1.4583^{*}$ \\
\hline & $\mathrm{R}$ & & $-1.8889^{*}$ & $-1.4167^{*}$ & -0.9643 & $-1.5500^{*}$ \\
\hline \multirow[t]{2}{*}{ G } & M & $-1.6000^{*}$ & -0.1354 & 0.0285 & -0.3167 & -0.3646 \\
\hline & $\mathrm{R}$ & $-1.9107^{*}$ & -0.7326 & -0.5417 & -0.631 & -0.4563 \\
\hline M & $\mathrm{R}$ & -0.3107 & -0.5972 & -0.5702 & -0.3143 & -0.0917 \\
\hline
\end{tabular}

Based on Table 5, the belief control is used to a greater extent in revival stage for three organizational life cycle indicators. Those are environment uncertainty, strategic planning, market and distribution. Also, the use of belief system has the biggest significance for strategic planning, followed by innovation, market and distribution, and environment uncertainty. For diversification indicator, belief control is not significant in every stage 
with the same explanation as before. The reason for belief system is used to greater extent in revival stage, is organization needs to do market expansion and new growth in the midst of competitive markets. Therefore, the decision-making style is required to be innovative, proactive, and risk-taking action to obtain a rapid growth through innovation, acquisition, and diversification. Other studies stated that belief system use to inspire and motivate employee to search, explore, create, and strive to act correctly [16]. Also, organization needs to identify challenges and opportunities in external environment with a new strategic planning. Hence, it creates many strategy changes and causes an organization uses belief system. Moreover, [1] claims that formal belief system such as, vision and mission which are implemented in a mature organization. Regarding to the discussion, $\mathrm{H} 2$ is partially accepted.

TABLE 5: SPSS Test of Belief Control System.
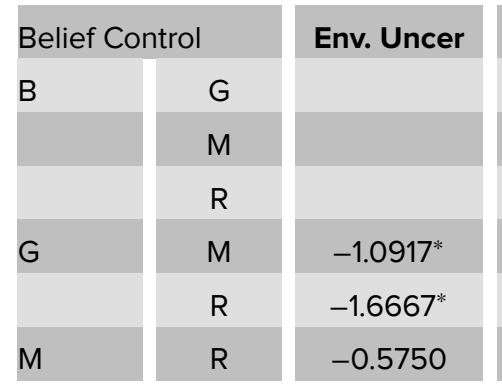

\begin{tabular}{|c|}
\hline Strat. Plan \\
\hline$-1.6250^{*}$ \\
$-1.9444^{*}$ \\
\hline$-2.5972^{*}$ \\
-0.3194 \\
\hline$-0.9722^{*}$ \\
\hline-0.6528 \\
\hline
\end{tabular}

\begin{tabular}{|c|}
\hline Divers. \\
\hline-0.125 \\
-0.5395 \\
-1.0556 \\
-0.4145 \\
\hline-0.9306 \\
\hline-0.5161 \\
\hline
\end{tabular}

\begin{tabular}{|c|}
\hline Mark \& Dis \\
\hline-0.7292 \\
\hline$-1.2500^{*}$ \\
\hline$-1.7054^{*}$ \\
-0.5208 \\
\hline-0.9762 \\
\hline-0.4554 \\
\hline
\end{tabular}

\begin{tabular}{|c|}
\hline Innov. \\
\hline$-1.6875^{*}$ \\
$-2.1875^{*}$ \\
$-2.1083^{*}$ \\
-0.5 \\
\hline-0.4208 \\
\hline 0.0792 \\
\hline
\end{tabular}

Based on Table 6, diagnostic control is used to a greater extent in revival stage for all organizational life cycle indicators. The use of diagnostic control has the biggest significance for strategic planning, followed by innovation, diversification and environment uncertainty. It means that while the organization establishes a strategic planning and identifies opportunities and challenges in the external business environment, organization needs diagnostic control as a monitoring tool. Based on the result above, it concludes that $\mathrm{H} 3$ is rejected, because the diagnostic control system is used to a greater extent in the revival stage compared to other stages. This is in accordance with previous researcher [28], though it is partially accepted.

TABLE 6: SPSS Test of Diagnostic Control System.

\begin{tabular}{|l|l|}
\multicolumn{2}{|c|}{ Diag. Control } \\
\hline B & G \\
\hline & M \\
\hline & R \\
\hline G & M \\
\hline & R \\
\hline M & R \\
\hline
\end{tabular}

\begin{tabular}{|c|}
\hline Env. Uncer \\
\hline \\
\hline-0.4250 \\
\hline$-1.1071^{*}$ \\
\hline$-0.6821^{*}$ \\
\hline
\end{tabular}

\begin{tabular}{|c|}
\hline Strat. Plan \\
\hline-0.6875 \\
$-1.2361^{*}$ \\
$-1.6389^{*}$ \\
$-0.5486^{*}$ \\
\hline$-0.9514^{*}$ \\
-0.4028 \\
\hline
\end{tabular}

\begin{tabular}{|c|}
\hline Divers. \\
\hline-0.7083 \\
\hline-0.6491 \\
\hline$-1.1667^{*}$ \\
\hline 0.0592 \\
\hline-0.4583 \\
\hline$-0.5175^{*}$ \\
\hline
\end{tabular}

\begin{tabular}{|c|}
\hline Mark \& Dis \\
\hline-0.3750 \\
\hline-0.2625 \\
\hline$-1.0357^{*}$ \\
\hline 0.1125 \\
\hline$-0.6607^{*}$ \\
\hline$-0.7732^{*}$ \\
\hline
\end{tabular}

\begin{tabular}{c|}
\hline Innov \\
\hline$-0.9688^{*}$ \\
$-0.9375^{*}$ \\
$-1.5667^{*}$ \\
0.0313 \\
\hline$-0.5979^{*}$ \\
$-0.6292^{*}$
\end{tabular}


Based on the Table 7, interactive control is used to a greater extent in revival stage for all organizational life cycle indicators. The use of interactive control has the biggest significance for environment uncertainty indicator, followed by strategic planning, innovation, and market and distribution. It shows that in environment uncertainty, organization needs interactive control to involve interaction and communication within the company to put organization in a better position in a dynamic and uncertain environment [46]. It can be concluded that $\mathrm{H} 4$ is partially accepted, and in accordance with previous studies $[4,7,8,11,28,46]$. From the findings, it can be concluded that organization, with high levels of uncertainty environment and strategic planning, uses more interactive control.

TABLE 7: SPSS Test of Interactive Control System.

\begin{tabular}{|c|c|c|c|c|c|c|}
\hline \multicolumn{2}{|c|}{ Interac. Control } & \multirow[t]{2}{*}{ Env. Uncer } & \multirow{2}{*}{$\begin{array}{l}\text { Strat. Plan } \\
-0.4750^{*}\end{array}$} & \multirow{2}{*}{$\begin{array}{l}\text { Divers. } \\
-0.3667\end{array}$} & \multirow{2}{*}{$\begin{array}{c}\text { Mark \& Dis } \\
-0.7000^{*}\end{array}$} & \multirow{2}{*}{$\begin{array}{c}\text { Innov. } \\
-0.9250^{*}\end{array}$} \\
\hline B & G & & & & & \\
\hline & $M$ & & $-1.1889^{*}$ & $-0.6632^{*}$ & $-0.5900^{*}$ & $-0.8333^{*}$ \\
\hline & $\mathrm{R}$ & & $-1.5111^{*}$ & $-1.0222^{*}$ & $-1.1429^{*}$ & $-1.4267^{*}$ \\
\hline \multirow[t]{2}{*}{ G } & $M$ & $-1.6000^{*}$ & $-0.7139^{*}$ & $-0.2965^{*}$ & 0.1100 & 0.0917 \\
\hline & $\mathrm{R}$ & $-1.9107^{*}$ & $-1.0361^{*}$ & $-0.6556^{*}$ & $-0.4429^{*}$ & $-0.5017^{*}$ \\
\hline M & $\mathrm{R}$ & -0.3107 & $-0.3222^{*}$ & $-0.3591^{*}$ & $-0.5529^{*}$ & $-0.5933^{*}$ \\
\hline
\end{tabular}

\section{Conclusion}

The results indicate that belief, boundary, interactive, and diagnostic control systems are used at a greater extent in the revival stage in all stages of the organizational life cycle. The use of boundary and interactive control systems is the most significant for environment uncertainty. It shows that in uncertain environment, such as customer tastes and unpredictable production technology, increasing competition intensity and external influences, as well as differences in competition tactics, customer tastes, product lines and corporate distribution channels.

With the existence of a boundary control system, organization can provide restrictions and rules for employees in finding, exploring, and experimenting with environmental uncertainty. This serves to keep the organization in an uncertain condition, and employees can still obey the rules. On the other hand, the use of interactive control systems makes organization engage in interaction and communication within the company to put them in a better position in a dynamic and uncertain environment.

The use of belief and diagnostic control system has the greatest significance for strategic planning. For companies that do strategic planning and identification of challenges and opportunities in the external business environment, the belief control is 
needed by the company. When the external environment of the company becomes more competitive, the company will entrust the task to employees to create new strategies than to copy competitiveness strategies. The company will control through the vision, mission and values of the company in order for the strategy is in line with the company's desires. On the other hand, the diagnostic control system also plays a role in monitoring and evaluating the strategies to continue to survive in a competitive environment.

This research is expected to help managers to gain insight into the types of controls that are often used in each stage of the organization's life cycle in order to help managers make the right decisions in managing strategies in the company. With the results obtained from this study, managers can determine the right controls to be applied in the company. Although, companies often find it difficult to determine organizational life cycles, companies need to be more aware of developments in the company and managers can classify companies into the stages of the organization's life cycle based on the available criteria. This research is expected to be able to be an additional literature reference for the next researcher, despite the limited data and scope contained in this study.

\section{References}

[1] Kantola, T. (2017). Management control systems during early life cycle phases: A case study in the social and healthcare services sector. Master's thesis, Aalto University Master of Business, Helsinki, Finland.

[2] Miller, D. and Friesen, P. H. (1984). A longitudinal study of the corporate life cycle. Management Science, vol. 30, no. 10, pp. 1161-1183.

[3] Su, S., Baird, K., and Schoch, H. (2015). The moderating effect of organisational life cycle stages on the association between the interactive and diagnostic approaches to using controls with organisational performance. Management Accounting Research, vol. 26, pp. 40-53.

[4] Ferreira, A. and Otley, D. (2009). The design and use of management control systems: An extended framework for analysis. Management Accounting Research, vol. 20, no. 4, pp. 263-282.

[5] Antony, R. N. and Govindarajan, V. (2011). Management Control System (twelfth edition). Jakarta: Salemba Empat.

[6] Malmi, T. and Brown, D. A. (2008). Management control systems as a packageOpportunities challenges and research directions. Management Accounting Research, vol. 19, pp. 287-300. 
[7] Chenhall, R. H. (2003). Management control system design within its organizational context: Findings from contingency-based research and directions for the future. Accounting, Organizations and Society, vol. 28, no. 2-3, pp. 127-168.

[8] Bisbe, J. and Otley, D. (2004). The effects of the interactive use of management control systems on product innovation. Accounting, Organizations and Society, vol. 29, no. 8, pp. 709-737.

[9] Davila, T. (2000). An empirical study on the drivers of management control systems' design in new product development. Accounting, Organizations and Society, vol. 25, no. 4/5, pp. 383-409.

[10] Kober, R., Ng, J., and Paul, B. J. (2007). The interrelationship between management control mechanism and strategy. Management Accounting Research, vol. 18, no. 4, pp. 425-452.

[11] Henri, J. (2006). Management control systems and strategy: A resource-based perspective. Accounting. Organizations and Society, vol. 31, no. 6, pp. 529-558.

[12] Merchant, K. A. and Otley, D. T. (2007). A review of the literature on control and accountability, in C. S. Chapman, A.G. Hopwood, and M.D. Shield (eds.) Handbook of Management Accounting Research. Oxford: Elsevier.

[13] Langfield-Smith, K. (1997). Management control systems and strategy: A critical review. Accounting, Organizations and Society, vol. 22, no. 2, pp. 207-232.

[14] Ramos, M. M. and Hidalgo, F. G. (2003). From diagnostic to interactive style of management control. Management Research News, vol. 26, pp. 21-31.

[15] Simons, R. (1995). Levers of control: How managers use innovative control systems to drive strategic renewal. Boston, MA: Harvard Business School Press.

[16] Chandler, A. D. (1962). Strategy and Structure: Chapters in the History of the American Industrial Enterprise. Cambridge, MA: MIT Press.

[17] Greiner, L. E. (1998). Evolution and revolution as organizations grow (updated). Harvard Business Review, vol. 76, no. 3, pp. 55-68.

[18] Tam, S. and Gray, D. E. (2016). Organisational learning and the organisational life cycle: The differential aspects of an integrated relationship in SMEs. European Journal of Training and Development, vol. 40, no. 1, pp. 2-20.

[19] Smith, K., Mitchell, T., and Summer, C. (1985). Top level management priorities in different stages of the organizational life cycle. The Academy of Management Journal, vol. 28, no. 4, pp. 799-820.

[20] Greiner, L. E. (1972). Evolution and revolution as organizations grow. Harvard Business Review, July-August, pp. 37-46. 
[21] Churchill, N. C. and Lewis, V. L. (1983). The five stages of small business growth. Harvard Business Review, May-June, pp. 30-50.

[22] Quinn, R. and Cameron, K. (1983). Organizational life cycles and shifting criterias of effectiveness: Some preliminary evidence. Management Science, vol. 29, pp. 33-51.

[23] Silvola, H. (2008). Design of MACS in growth and revival stages of the organizational life cycle. Qualitative Research in Accounting \& Management, vol. 5, no. 1, pp. 27-47.

[24] Victor, B. and Boynton, A. C. (1998). Invented Here: Maximizing Your Organization's Internal Growth and Profitability. Boston, MA: Harvard Business School Press.

[25] Drazin, R. and Kazanjian, R. K. (1990). A reanalysis of Miller and Friesen's life cycle data. Strategic Management Journal, vol. 11, no. 4, pp. 319-325.

[26] Kazanjian, R. K. and Drazin, R. (1990). A stage-contingent model of design and growth for technology based new ventures. Journal of Business Venturing, vol. 5, no. 3, pp. 137-150.

[27] Miller, D. and Friesen, P. H. (1982). Innovation in conservative and entrepreneurial firms: two models of strategic momentum. Strategic Management Journal, vol. 3, no. 1, pp. 1-25.

[28] Su, S., Baird, K., and Schoch, H. (2017). Management control systems: The role of interactive and diagnostic approaches to using controls from an organizational life cycle perspective. Journal of Accounting \& Organizational Change, vol. 13, no. 1, pp. $2-24$.

[29] Auzair, S. M. and Langfield-smith, K. (2005). The effect of service process type, business strategy and life cycle stage on bureaucratic MCS in service organizations. Management Accounting Research, vol. 16, no. 4, pp. 399-421.

[30] Kallunki, J. and Silvola, H. (2006). The effect of organizational life cycle stage on the use of activity-based costing. Management Accounting Research, vol. 19, pp. 62-79.

[31] Simons, R. (1987). Accounting control systems and business strategy: An empirical analysis. Accounting, Organizations and Society, vol. 12, no. 4, pp. 357-374.

[32] Anthony, R. N. and Govindarajan, V. (2007). Management Control Systems, vol. 10. NY: McGraw-Hill.

[33] Merchant, K. A. and van der Stede, W. A. (2011). Management control systems: Performance measurement, evaluation and incentives (third edition). Harlow, UK: Prentice Hall.

[34] Otley, D. T., Broadbent, J. M., and Berry, A. J. (1995). Research in management control: An overview of its development. British Journal of Management, vol. 6, S31-S34.

[35] Simons, R. (1994). How new top managers use control systems as levers of strategic renewal. Strategic Management Journal, vol. 15, pp. 169-189. 
[36] Simons, R. (2000). Performance Measurement and Control Systems for Implementing Strategy. Upper Saddle River, NJ: Prentice Hall.

[37] Hambrick, D. C. (2007). Upper echelons theory: An update. Academy of Management Review, vol. 32, pp. 334-343.

[38] Mundy, J. (2010). Creating dynamic tensions through a balanced use of management control systems. Accounting, Organizations and Society, vol. 3, no. 5, pp. 499-523.

[39] Su, S., Baird, K., and Schoch, H. (2014). The moderating effect of organisational life cycle stages on the association between the interactive and diagnostic approaches to using controls with organisational performance. Management Accounting Research, Forthcoming.

[40] Koberg, Ch. S., Uhlenbruck, N., and Sarason, Y. (1996). Facilitators of organizational innovation: The role of life-cycle stage. Journal of Busines Venturing, vol. 11, pp. 133149.

[41] Kimura, S. and Mourdoukoutas, P. (2000). Effective integration of management control systems for competing in global industries. European Business Review, vol. 12, no. 1, pp. 41-45.

[42] Greiner, L. E. (1998). Evolution and revolution as organizations grow (updated). Harvard Business Review, vol. 76, no. 3, pp. 55-68.

[43] Cardinal, L. B., Sitkin, S. B., and Long, C. P. (2004). Balancing and rebalancing in the creation and evolution of organizational control. Organization Science, vol. 15, no. 4 , pp. 411-431.

[44] Abernethy, M. A. and Brownell, P. (1999). The role of budgets in organizations facing strategic change an exploratory study. Accounting, Organizations and Society, vol. 24, pp. 189-204.

[45] Amabile, T. M. (1988). A model of creativity and innovation in organizations. Research in Organizational Behaviour, vol. 10, pp. 123-167.

[46] Widener, S. K. (2007). An empirical analysis of the levers of control framework. Accounting, Organizations and Society, vol. 32, no. 7-8, pp. 757-788.

[47] Mohamed, R., et al. (2014). The relationship between strategic performance measurement system and organisational capabilities: The role of beliefs and boundary control systems. Asian Journal of Business and Accounting, vol. 7, no. 1, pp. 107-142. 